\title{
O Poder Judiciário e a concretização da Democracia Participativa
}

\author{
José Júlio da Ponte Neto*
}

Sumário: Introdução; 1. A problematização da Democracia Participativa; 2. O papel do Poder Judiciário à efetivação da Democracia Participativa. Conclusão. Referências.

\begin{abstract}
Resumo: A participação popular como realização da democracia participativa deve ser efetivada pelo Poder Judiciário, entendido como legítima instituição capaz de solucionar os diversos conflitos de interesses entre o Poder Executivo municipal e o exercício da cidadania. Para tanto pugna que o Poder Judiciário atue como elemento de superação de sua tradição conservadora, legitimando a democracia representativa.
\end{abstract}

Palavras-chave: Poder local; Poder Judiciário; Democracia participativa.

\begin{abstract}
The popular participation as accomplishment of participated democracy should be executed by the Judiciary Power, expert as legitimate institution capable to solve the several conflicts of interests between the municipal Executive Power and the exercise of the citizenship. For so much, it fights that the Judiciary Power acts as element of alteration of your conservative tradition, legitimating of representative democracy.
\end{abstract}

Keywords: Place Power; Judicial Power; Participated democracy.

\section{Introdução}

A consolidação do poder local é a afirmação da democracia e negação das políticas clientelistas. Seu exercício concretiza o significado do Município como expressão real do poder político exercido pelo cidadão, dada sua aproximação não apenas física como também em relação às suas necessidade materiais imediatas. A Constituição Federal de 1988, ao emancipar o Município da tutela organizatória e centralista do Estado-membro e da União, objetiva que sua autonomia estabeleça meios indispensáveis ao cumprimento das atribuições político-institucionais para a implementação de medidas eficazes à superação das desigualdades existentes entre seus habitantes.

\footnotetext{
* Doutor em Direito pela Universidade Federal de Pernambuco (UFPE), Mestre em Direito pela Universidade Federal do Ceará (UFC), Advogado e Professor da Graduação e do Programa de PósGraduação em Direito Constitucional/Mestrado e Doutorado da Universidade de Fortaleza (UNIFOR).
} 
A descentralização postula otimizar o gerenciamento da administração pública às conquistas sociais. O avanço do legado constitucional foi escrever a autonomia e a essencialidade da participação popular para a concretização de suas aspirações. $\mathrm{O}$ verticalismo trouxe, e ainda traz, conseqüências deletérias quanto à concepção de que a cidadania é a expressão material da própria soberania. O constitucionalismo brasileiro vigente veda a formação do cidadão como ser passivo e mero espectador dos resultados prometidos pelo governo local. Ao contrário, devem as entidades representativas da sociedade exercer atitudes de cooperação e de participação do planejamento municipal.

A participação-cidadã não é dispensável - ela é necessária como fonte das ações governamentais, mesmo porque discutir o poder local significa promover a dignidade do homem a partir de sua rua, de seu bairro, da escola do filho, do transporte coletivo, do posto de saúde e de outros interesses vitais.

\section{A problematização da Democracia Participativa}

Interagir no processo de planejamento e tomada de decisões das políticas públicas é um imperativo de renovação constante da democracia, razão pela qual a coisa pública adquire outro perfil quanto à intelecção dos interesses sociais, como também combate a ineficiência, a estagnação social, a corrupção e o clientelismo.

Através desse contexto, as instituições públicas municipais (Executivo e Legislativo) devem desenvolver, conjuntamente com os diversos agentes sociais, estratégias para solução dos problemas locais. A formação de processos de tomada de decisão dinamiza a sociedade para formatação da autonomia, da regulação e da organização de suas convivências. Como salientado Ângela Küster:

Um desenvolvimento sustentado segue o princípio, segundo o qual a sociedade não mais se organiza de cima para baixo, de forma centralizada e autoritária, mas sim conforme a pluralidade social, por meio de um processo dinâmico de tomada de decisões. Deve-se permitir bastante espaço aos cidadãos, a fim de que possam determinar com autonomia a organização de sua convivência. ${ }^{1}$

Ocorre que esse processo de emancipação política tem recebido dos gestores municipais críticas quanto à necessidade de maiores recursos para financiar a prestação dos serviços demandados. Contudo, dentro da dialeticidade, mais importante se torna a participação social em situações como essas de escassez de recursos, posto ser o processo ideal para a fixação de prioridades diante do quadro financeiro

${ }^{1}$ KÜSTER, Ângela. Democracia e sustentabilidade. Fortaleza: Konrad Adenauer. 2003, p. 20. 
da municipalidade. A questão é administrar racionalmente para atender o necessário, ainda que de forma mínima. O Município não pode mais promover desperdícios como outrora, quando as expectativas sociais eram supridas e mitigadas por esferas superiores de governos.

As formulações políticas no âmbito da municipalidade não podem se desenvolver pondo a sociedade na esfera de supletividade ou de marginalização. A democracia representativa é a politização do munícipe, não enquanto homem apenas, mas enquanto cidadão. Na esteira da negação de que a democracia representativa deve ser exercida tão somente pelos eleitos às casas legislativas, Bobbio afirma:

Os estados, que hoje nos habituamos a chamar de representativos, são representativos porque o princípio da representação está estendido também a numerosas outras sedes onde se tomam deliberações coletivas, como são as comunas, as províncias e na Itália também as regiões. Em outras palavras, um estado representativo é um estado no qual as principais deliberações políticas são tomadas por representantes eleitos, importando pouco se os órgãos de decisão são o parlamento, o presidente da República, o parlamento mais os conselhos regionais, etc. ${ }^{2}$

Comungando com o raciocínio exposto por Bobbio, não se trata de nova forma de democracia, mas da criação de novos espaços públicos, não apenas os tradicionalmente existentes, à democratização da sociedade em si. O cidadão, na sua intersubjetividade, deve se engajar e não ser desafetado dos assuntos públicos, sob pena de inocorrer a consistência do corpo social e dos preceitos democráticos. Por sua vez, afirma Christian Ruby que:

Assim, exprime-se o sentimento comum segundo o qual a política, qualquer que seja, não pode mais contentar-se em ser instrumental. Os cidadãos recusam-se a ser governados como antes, na desistência de todo poder sobre o curso das coisas em nome da tecnicidade da política (os expertos ou os dirigentes). Mais geralmente ainda, essa expressão acompanha a vontade de pôr a bordo as antigas estruturas de autoridade e de crença que enquadram os indivíduos dando de cima um certo sentido à existência deles. ${ }^{3}$

A intersubjetividade das relações sociais no vigente estágio constitucional, repise-se, suscita o caráter público-participativo do poder local, alicerçado no pluralismo de idéias (democracia pluralista), sobre dissensos para convergir e impedir desvios ou devaneios governamentais. Em outros termos, a feitura democrática da socieda-

\footnotetext{
${ }^{2}$ BOBBIO, Norberto. O futuro da democracia. São Paulo: Paz e Terra, 1987, p. 44.

${ }^{3}$ RUBY, Christian. Introdução à filosofia política. São Paulo: UNESP, 1997, p. 137.
} 
de, não apenas a democracia do Estado, estabelecerá bases promissoras de correta distribuição e controle sobre o poder. ${ }^{4}$

\section{O papel do Poder Judiciário à efetivação da Democracia Participativa}

Surge a relevante problematização sobre como efetivar a participação social se esse direito constitucionalmente estabelecido for direta ou indiretamente negado. A democracia representativa tem o desiderato de promover as interações sociais, elevando o nível da maturidade política, e proíbe a utilização de meios irracionais, violentos para o estabelecimento das vontades. Se ela é a verificação das competições culturais, políticas, econômicas e religiosas, também é a pressuposição da responsabilidade geral da superação desses conflitos no âmago da sociedade. O conflito e o consenso se integram e se valorizam.

Mecanismos ao cumprimento da respeitabilidade das regras constitucionais devem e são postos à disposição do processo democrático representativo contra vilipêndios. $\mathrm{O}$ (re)estabelecimento do processo participativo das relações sociais é concebido ao Poder Judiciário, proclamador da afirmação dos direitos, das garantias constitucionais.

O controle exercido pelo Judiciário traduz a extensão do ciclo de transformação da sociedade democrática que, agindo contra os agentes administrativos, nega a sua paralisia, ineficiência e obstruções. Para Giovanni Sartori:

No nosso século, as declarações de direitos foram expandidas de forma a incluir 'direitos afirmativos', de caráter social e material, tais como o direito à educação, ao emprego, aos serviços de saúde, etc. Sua função assumiu um aspecto inteiramente novo. Hoje, esses 'direitos' são mais importantes do que nunca, mas podemos especular sobre se sua transformação em coisas materiais pertencentes ainda ao contexto constitucional. ${ }^{5}$

Os conflitos emergidos reclamam a resolução do aparato estatal, caso contrário a ordem constitucional ficará comprometida. Conclamar a função jurisdicional do Estado tem por escopo restabelecer o equilíbrio das forças político-sociais, visto que é essencial

\footnotetext{
4 "Qualquer fator que for verdadeiramente comum é simplesmente um meio que o bem particular dos indivíduos. No caso seguinte, temos um fator comum que aparece ser mais que um meio, quando o homem reconhece que a cooperação com outros é a melhor maneira para atingir um fim e, quando eles formam uma associação para consegui-lo, cada membro da associação sente mais interesse no bem de seus associados". MABBOTT, J. D. O estado e o cidadão. Rio de Janeiro: Zahar, 1968, p. 105.

${ }^{5}$ SARTORI, Giovanni. Engenharia constitucional. Brasília: UNB, 1996, p. 210.
} 
à estrutura democrática. A bandeira do Judiciário está fincada na afirmação da ordem social e na negação das negações provenientes dos titulares investidos na administração pública. Concretizam-se o direito e as obrigações dos atores político-sociais.

A segurança jurídica que a sociedade espera e exige é a fixação da face concreta, real do Estado, esculpida pela cidadania e pela pluralidade das relações sociais dos seus idealizadores. Portanto, o arbítrio das decisões meramente subjetivas não se aplica ao ideal da soberania da sociedade brasileira contemporânea, concebida sob a ótica do alongamento da materialização dos espaços públicos e da intersubjetividade.

Nesse compasso segue Newton Albuquerque, ao escrever sobre o resgate da processualística das organizações democráticas:

A única alternativa para aqueles que defendem uma cosmovisão democrática da sociedade e de seus vínculos com o poder se situa em um necessário resgate da idéia de soberania, no intuito de reafirmar o sentido político do processo de formação da vontade nacional e de sua força incontrastável sobre os demais poderes privados que com ela colidam, resistindo assim à ação subversora dos poderes econômicos e sociais, opositores de um processo límpido e democrático de formação da vontade comunitária do Estado. Daí a tarefa ingente de dar vazão à construção de um Estado que, marcado pela cidadania e pelas vontades que o conformam, possa se magnificar em expressão superior da vontade popular e da nacionalidade. ${ }^{6}$

Por esse ideal desemboca no Judiciário o seu relevante papel de fazer valer, coercitivamente, o princípio do Estado Democrático de Direito, que é um princípio jurídico fundamental, mais precisamente os direitos fundamentais de terceira geração, justamente sobre a essência valorativa da solidariedade do Estado federal tendente ao equilíbrio entre as esferas federativas. Essa terceira geração corresponde aos direitos de cunho cultural, social, econômico e associativo, além dos relativos ao meio ambiente e ao desenvolvimento. ${ }^{?}$

\footnotetext{
${ }^{6}$ ALBUQUERQUE, Newton de Menezes. Teoria política da soberania. Belo Horizonte: Mandamentos, 2001, p. 146.

7 "Dotados de altíssimo teor de humanismo e universalidade, os direitos de terceira geração tendem a cristalizar-se neste fim de século enquanto direitos que não se destinam especificamente à proteção dos interesses de um indivíduo, de um grupo ou de um determinado Estado. Têm primeiro por destinatário o gênero humano mesmo num momento expressivo de sua afirmação como valor supremo em termos de existencialidade concreta”. BONAVIDES, Paulo. Curso de direito constitucional. São Paulo: Malheiros, 1993, p. 481. No mesmo pensamento expõe Albuquerque Rocha: "Nos últimos anos, é corrente na literatura jurídica especializada a alusão aos direitos fundamentais da 'terceira geração' e a igualdade material o valor subjacente aos direitos da segunda geração (direitos de cunho social, econômico, cultural, etc.), os direitos de terceira geração teriam como fundamento o valor da solidariedade, já que são caracterizados por sua incidência universal na vida das pessoas e por exigirem, para sua efetivação, os esforços da comunidade a pressupor a solidariedade". ROCHA, José de Albuquerque. Estados sobre o Poder Judiciário. São Paulo: Malheiros, 1995, p. 58.
}

Revista Seqüência, no 56, p. 205-224, jun 2008. 
Agora, o foco da concreção desses postulados fundamentais dirige-se ao Judiciário e sua formação tradicional positivista-legalista, isto é, detentores da apoliticidade. Existem razões de ordem político-econômica em submeter os magistrados como meros instrumentos de aplicação da lei. Interpretar, neste caso, leva o sentido de explicitar mecanicamente, quedando-se à vontade dos demais poderes, ou seja, repetição secular do gesto de Pilatos. Em nome da sociedade garante-se "a paz social". Em Kelsen a expressão "paz do Direito" resulta na utilização de meios coercitivos empregados pela sociedade, detentora do "monopólio da força".

A problematização que se invoca diz respeito ao Direito e sua interpretação como valor de manipulação da elite dirigente, não importando seus pendores ideológicos. Quando Kelsen inicia sua exposição sobre o conceito de direito, parte da negação de que o Direito seja uma regra, mas uma sistematização de regras dando ou procurando dar certa unidade à conduta humana. Entretanto, ao não explicar a libertação do conceito de Direito da concepção do sentimento de justiça, dispondo ser uma justificação política, não científica, incorre em tratar como irracional a idéia de justiça. Com efeito, adjetivar o conteúdo direito/justiça como proveniente de determinada ordem social, mas desprovido de conteúdo científico, nega que o Estado seja a confirmação da sociedade e não considera ser a justiça interpretada como "um julgamento de valor", como a realização do Direito. ${ }^{9}$ O direito manifesta-se através da força e se explica pela manipulação dos conceitos. Exemplo: o conceito de cidadania emitido por Kelsen diferencia-se do contemporâneo alcance que lhe é emprestado. ${ }^{10} \mathrm{Na}$ manipulação dos conceitos e do próprio Direito advém a força limitadora de avanços de determinados segmentos sociais. Agrava a razão da existência de um "Estado Democrático de Direito" se uma sociedade não tem conhecimento de sua identidade nacional.

A respeito da separação de poderes e democracia estabelecida por Kelsen move indefinidamente a dialeticidade tese-antítese e síntese. Com efeito:

O princípio de uma separação de poderes, compreendido ou interpretado como princípio de divisão de poderes, não é essencialmente democrático. Ao contrário, corresponde a idéia de democracia é a noção de que todo poder deve estar concentrado no povo e, onde não é possível a democracia direta, mas apenas a indireta, que todo o poder deve ser exercido por um órgão colegiado cujos membros sejam eleitos pelo povo e juridicamente responsáveis para com o povo. ${ }^{11}$

\footnotetext{
${ }^{8}$ KELSEN, Hans. Teoria geral do direito e do estado. São Paulo: Martins Fontes, 1995, p. 28.

${ }^{9}$ Ibid, p. 14.

${ }^{10}$ Ibid, p. 234.

${ }^{11}$ KELSEN, Hans, op. cit., p. 275.
} 
Contemporaneamente, o exercício da cidadania, na invocação do cumprimento dos preceitos constitucionais vigentes, está alterando essa tradição kelseniana da apoliticidade do Poder Judiciário. A politização desse Poder, isto é, o engajamento paulatinamente crescente sobre as questões sociais, coloca seus membros num patamar também de atores sociais, fazendo com que a sociedade gradativamente possa dissipar a concepção de um Poder insensível e inacessível aos conflitos relacionados à atuação da democracia representativa e participativa.

A recorrente expressão judicialização das relações sociais da política no país não está partindo apenas da negação daquela mentalidade ainda presente e solidificada de corpos de magistrados cuja produção jurisprudencial é formulada em derredor da superior vontade do Legislativo (detentor exclusivo, em razão do voto, da legitimidade das deliberações coletivas) e da lei (paz social sob a força), como, principalmente, da intelecção de que fazem parte do meio social e que sentem as mesmas necessidades dos seus pares. Da postura de acomodação à quebra de preconceitos para elevação de outros conceitos, produzidos como instrumentos de exposição do conhecimento da sociabilidade e historicidade, mesmo porque o Direito não é constituído apenas de regras, mas de conteúdo principiológico.

A judicialização tanto da política como das relações sociais promove: a) afirmação da cidadania; b) afirmação da democracia representativa e participativa; c) fortalecimento da sociedade organizada; d) consolidação dos valores fundamentais dos direitos do indivíduo e da coletividade; e) valoração da administração da coisa pública; f) apropriação de atos governamentais da municipalidade pelo público; g) formação da consciência crítica; e h) desmistificação do conceito de interesse público (compreendido não mais como interesse do chefe do Executivo).

O processo histórico da judicialização das relações políticas e sociais tem o condão de desalgemar o cidadão para exercer os seus direitos sem receio de ser adjetivado apenas como destinatário dos resultados das políticas públicas gestadas nos gabinetes. Ao contrário, efetivar-se-á nele a condição de soberano e promotor de seu próprio destino social. Para Calamandrei:

Os juízes são como os membros de uma ordem religiosa: é preciso que cada um deles seja um exemplo de virtude, se não quiser que os crentes percam a fé [...]. Conheci muitos juizes indolentes, desatentos, carentes de vontade, prontos a se deter na superfície, para fugir do duro trabalho de escavação, que quem deseja descobrir a verdade tem de enfrentar. [...] Mas conheci alguns (os melhores) que, apesar de sobrecarregados, conseguiam, perdendo horas de sono, estudar com escrupulosa diligência todas as causas a eles confiadas e expô-las em câmaras de conselho sem esquecer a vírgula de um documento. ${ }^{12}$

${ }^{12}$ CALAMANDREI, Piero. Eles, os juizes. São Paulo: Martins Fontes, 1995, p. 278. 
A perspectiva de concretização da judicialização nos processos mencionados requer modificação de valores, conceitos, conhecimentos aprofundados das demais ciências humanas e não apenas a do Direito, mesmo porque a Constituição encerra princípios, preceitos e valores que estão a exigir um processo interpretativo tendo por base inicial a compreensão da comunidade formada por seus conteúdos históricos e ético-normativos. A Constituição deve ser realizada, executada. A partir do seu primeiro artigo anuncia que a federação é um Estado Democrático de Direito, compreendendo como elementos nucleares, magnânimos: a cidadania, a dignidade da pessoa humana e o pluralismo político. Acrescenta-se, expondo que são seus objetivos dentre outros: construir uma sociedade solidária, garantir o desenvolvimento nacional, bem como reduzir as desigualdades sociais e regionais (art. $3^{\circ}$ ). Portanto, o escopo de realizar a Constituição apresenta o ingresso do cidadão no complexo processo de sistema político-participativo.

Na busca pela integração da cidadania nas esferas públicas, Randolph Lucas faz um questionamento apropriado e cuja resposta incidirá na postura do Poder Judiciário e sua mudança valorativa de atuação:

À medida que uma sociedade torna-se maior, mais heterogênea e mais sofisticada, a simples indagação sobre se ela é democrática ou não, no sentido grego original da palavra, fica cada vez menos significativa e deve ser substituída em parte por questões sob até que ponto os princípios de justiça e de liberdade são observados e, sobretudo, sobre até que nível o povo pode participar do processo de governo. ${ }^{13}$

É justamente sobre o grau de participação-cidadã no "processo de governo" que eleva a problematização de atuação do Judiciário e a materialização da democracia representativa ao mesmo tempo. Como órgão do Estado e membro do seu corporativismo, não lhe é dado invocar dentre as premissas ao julgamento o interesse público como conceito excludente para inovar. O interesse público utilizado para tomada de decisões não é, e nem pode mais ser, o interesse de terceiras pessoas ocupantes de cargos no Executivo. O interesse público é o interesse da sociedade, do coletivo, é a manifestação do poder soberano. Afirmar que uma decisão, que acaso venha a ser tomada, agravará a crise da existência do próprio Estado para sensibilizar o voto do Judiciário em prol do Executivo é desabonar a própria inteligência de seus componentes, visto que solapar a existência do Estado é fragilizar a essência mesma da sociedade que lhe deu vida.

Em verdade, a "crise existencial" por que passa penetrou a consciência do julgador e resume-se na aceitação ou não da assertiva advinda de Antoine Garapon ${ }^{14}$ :

${ }^{13}$ LUCAS, John Randolph. Democracia e participação. Brasília: UNB, 1975, p. 37. 
ficar com o Estado julgador, promovedor da justiça, ou colocá-lo também como Estado julgado, questionado. A resposta ou respostas não podem ser sintetizadas apenas em relação ao Estado versus indivíduo, mas principalmente no conflito que exigirá do Estado o fiel e exato cumprimento de seus objetivos fundamentais (art. $3^{\circ}$, da Constituição): construir uma sociedade livre, justa e solidária, por exemplo.

A democracia brasileira, a partir dos ditames constitucionais, revela a necessidade da reorganização administrativa das esferas públicas, não mais encapsuladas durante os mandatos dos governantes. Ao contrário, as ações administrativas devem ser direcionadas à permanente dinamização provocada pela participação das entidades comunitárias no processo decisório acerca da coisa pública. Impedir essa interação legitimadora das ações políticas por parte do Judiciário é comparar o exercício da cidadania àquele ocupante de cargo comissionado demissível ad nutun. Afirma Garapon:

Em um sistema provedor, o Estado é todo poderoso e pode tudo preencher, corrigir, tudo suprir. Por isso, diante de suas falhas, a esperança se volta para a justiça [...]. A cooperação entre os diferentes atores da democracia não é mais assegurada pelo Estado mas pelo direito, que se coloca, assim, como a nova linguagem política na qual são formuladas as reivindicações políticas. A justiça torna-se um espaço de exigibilidade da democracia. Ela oferece potencialmente a todos os cidadãos a capacidade de interpelar seus governantes, de tomá-los ao pé da letra e de intimá-los a respeitarem as promessas contidas na lei. A justiça lhes parece oferecer a possibilidade de uma ação mais individual, mais próxima e mais permanente que a representação política clássica, intermitente e distante. ${ }^{15}$

Reside nessas idéias a funcionalidade do papel do Judiciário em superação ao liberal legado de simples aplicador do Direito, árbitro dos conflitos individuais ou coletivos, mediador para garantir a ordem social e jurídica. É a expressão própria do modelo corporativista estatal verticalizante, mantenedor da unidade dos órgãos do Estado. O novo papel que se escreve avança contra a complacência diante dos conflitos sociais para promovente de políticas públicas à modificação da realidade existente. Modificá-la requer interferência positivada para reduzir esses conflitos, isto é, legitimando a vontade do corpo social, interferindo sobre o curso dessa realidade. Acentua Albuquerque Rocha:

O papel do Judiciário, no Brasil, como do resto do terceiro mundo em geral, aprofunda o fosso que o separa do povo, trazendo à baila o grave problema da

\footnotetext{
${ }^{14}$ GARAPON, Antoine. O juiz e a democracia. Rio de Janeiro: Revan, 2001, p. 42.

${ }^{15}$ Idem. Op. cit., pp. 48, 49 e 50.
} 
tensão entre o Judiciário e a democracia, cuja principal conseqüência é o aparecimento de uma crise de identidade do juiz, que se manifesta do desencontro entre as opiniões do povo a níveis cada vez mais elevados de justiça, igualdade e dignidade, e o comportamento do Judiciário, de negação sistemática dessas aspirações. ${ }^{16}$

A crise de identidade que atinge o Judiciário advém da negação da dogmática jurídica jungida a regras de conformismo até então inabaláveis, ou seja, manutenção e conservação de parâmetros interpretativos tradicionalmente fixados, portanto estáticos, aplicados para manter coerência da estrutura do poder. Em suma, o conflito interno da magistratura está em continuar concebendo o direito como técnica, desideologizada ou não. Por desideologizar pode-se partir da premissa de prévia ideologização que se tornou hermética, posto ser "verdadeira", "inabalável", "dogmática". Porém, superar a manutenção das estruturas vigentes também pressupõe a absorção de outra ideologia que possa ser considerada da mesma maneira o conteúdo da "única verdade". ${ }^{17}$

A crise permanece quando se toma essa postura írrita de mantenedor da "paz social", isto é, do ordenamento jurídico posto, pressupondo que existe óbice de interferência entre governantes e governados, como se fossem limitações fronteiriças entre Estados soberanos. Dogmatiza-se o entendimento de Pareto e Mosca de que a existência da elite governante como controladora da sociedade, uma vez que o mandato conferido por essa sociedade democrática erige uma cláusula contratual legitimadora de sua aplicação pela magistratura, caso seja questionada. Reduz-se o conceito de interesse público predominantemente sob a ótica do administrador da coisa pública.

E mais: a democracia representativa é concebida como manifestação da esfera político-partidária congressual. Nos debates entre os parlamentares de diversas correntes culturais, ideológicas, econômicas etc., fluirão os resultados procurados pela sociedade que os sufragou e oportunamente os julgará pelos seus atos ou omissões através da renovação ou não do voto.

A justificação da permanência da postura tradicional do Judiciário parte da reafirmação do liberalismo no sentido de qual perspectiva de relações sociais deve ser julgada como racionalmente aplicável para evitar o agravamento do dissenso da

\footnotetext{
${ }^{16}$ ROCHA, José de Albuquerque. Estudos sobre o Poder Judiciário. São Paulo: Malheiros, 1995, p. 142.

17 “O conteúdo ideológico atravessa toda a estrutura da dogmática por estar contido no próprio dogma e, como bem nota Viehweg, não se deve preterir determinada teoria jurídica através da pecha de 'mera ideologia', haja vista que todo discurso dogmático segue uma linha ideológica e não descritiva, buscando como efeito a crença e não o conhecimento neutral e seus postulados". ADEODATO, João Maurício. Ética e retórica. São Paulo: Saraiva, 2002, p. 35.
} 
própria existência do Estado democrático. Ao julgador, na mitigação dessas forças, não ousará desafiar a ordem tradicionalmente estabelecida, negando o apelo dialético em prol das concepções já padronizadas porque eficazmente justificadas em estágios históricos e evolutivos anteriores. A prudência utilizada em nome da tradição evita o enfrentamento da identificação das relações sociais. O juízo de valor constitutivo da adesão à tradição inadmite rupturas, frustrando, pois, expectativas de avanços. Consolidou-se o argumento segundo o qual a tradição do Judiciário foi concebida pelas práticas reiteradas de justificação nacional e históricas de determinada sociedade.

Porém, promover rupturas em favor das teses emancipadoras do intelecto do magistrado é erigir outra maturidade à efetivação do processo participativo da gestão pública, conforme entende Macintyre:

\begin{abstract}
Esse tipo de dissolução de certezas historicamente fundadas é a marca de uma crise epistemológica. A solução para uma crise epistemológica genuína requer a invenção ou a descoberta de novos conceitos, e a estruturação de um novo tipo ou novos tipos de teoria que satisfaçam três exigências muito precisas. Em primeiro lugar, se este esquema conceitualmente enriquecido e, em alguns aspectos, radicalmente novo, deve por fim à crise epistemológica, ele deve fornecer uma solução aos problemas que se revelaram intratáveis, anteriormente, de como sistemático e coerente. Em segundo lugar, deve também fornecer uma explicação justamente naquilo que tornara a tradição estéril ou incoerente, ou ambas, antes que ela adquirisse esses novos recursos. E, em terceiro lugar, essas duas tarefas iniciais devem ser realizadas de modo a apresentar a continuidade fundamental das novas estruturas conceituais e teóricas com relação às crenças comuns, em cujos termos a tradição de pesquisa tenha se definido até então. ${ }^{18}$
\end{abstract}

Ainda que se levantem prognósticos mais otimistas da "judicialização", no Brasil, afora decisões que acusam sua verificação perante os juizes a quo, no âmbito superior, ou seja, na esfera hierarquicamente, isso não acontece na maioria das vezes. Quando muito sua ocorrência tem sido tenuamente atestada.

Essa verificação conservadora é o reconhecimento que a função do Judiciário, com todo seu significado social, não pode ser independente da estrutura dos poderes do Estado em assuntos que lhe digam especial interesse de transformação, dado que potencialmente pode desempenhar no desenvolvimento das interpreta-

\footnotetext{
${ }^{18}$ MACINTYRE, Alasdair. Justiça de quem? Qual racionalidade? São Paulo: Loyola, 1991, p. 388389.
} 
ções normativas constitucionais ou infraconstitucionais significativas alterações à existência da sociedade. ${ }^{19}$

Os conflitos sociais evoluem o conjunto do corpo social e é justamente para evitar essa evolução no sentido aproximado de revolucionário que se elaboram sistemas ideológicos conservadores, dispondo que o Poder Judiciário tem condão de integrar as normas legislativas com a sociedade de forma hierarquizada, dando-lhe falsa satisfação de equilíbrio, quando em verdade a torna inerte em razão do receio do aparato coercitivo do Estado. Sob esse prisma, a frustração da sociedade quanto à satisfação de pugnar pelos seus direitos se manifesta, tornando-a incrédula, imóvel, por vezes dócil aos arranjos políticos.

Dahrendorf, tecendo análise comportamental dos juizes alemães de sua época, retrata:

Em termos gerais, a estabilidade social inclina o indivíduo a adotar antes uma conduta que, de acordo com as preferências políticas, pode designar-se como conservadora e enraizada no tradicional, ou como reacionária, rígida e de horizontes limitados. Talvez o termo mais adequado seja, neste ponto, a de atitude conservadora; uma atitude, por conseguinte, que aceita o 'status quo' político e social e, em princípio, o defende com certa reserva contra qualquer atividade política. ${ }^{20}$

Tece suas análises considerando vários aspectos da formação social, política e econômica do corpo de magistratura, asseverando, apesar do conteúdo acadêmico ao exercício do cargo, limitações intelectuais para entender as complexas relações sociais, cujo alcance restringe-se ao seu estrato social próprio, daí vivam e entendam a sociedade sob prismas de elevada miopia. Como membro de uma "justiça de classe", nada mais natural que produzir sentenças do interesse da classe dominante. Acrescenta-lhe como negativo a própria formação recebida para preservar a autoridade de lei para garantir a ordem e segurança dos assuntos públicos e políticos.

\footnotetext{
19 "Na mesma intensidade em que permanece a discussão sobre o raio de ação de uma corte constitucional que alcance até as questões políticas, resta também como um desafio, sob a ótica de uma teoria política da democracia, a conciliação deste problema com a importância da participação popular e o valor dos representantes legitima e diretamente eleitos. É que se se concede poderes a uma corte constitucional não eleita diretamente pelo povo de resolver questões políticas, tal atitude se deixa traduzir de maneira desfavorável à democracia direta, na medida em que pode esta corte sobreporse à vontade das urnas“. LIMA, Martônio Mont'Alverne Barreto. Judicialização da política e comissões parlamentares de inquérito: um problema da teoria constitucional da democracia. In: SCAFF, Fernando Facury. Constitucionalizando direitos - 15 anos da Constituição Brasileira de 1988. Rio de Janeiro: Renovar, 2003, p. 218.

${ }^{20}$ DAHRENDORF, Ralf. Sociedade e liberdade. Brasília: UNB, 1981, p. 127.
} 
A harmonia desse sistema conservador se explica mediante a utilização do binômio poder e domínio para justificar a subordinação da sociedade através da integração do agir entre o Executivo, Legislativo e Judiciário. A este cabe a tarefa complementar de manter a aparente coesão das relações sociais. Compete ao Direito o meio empregado para a efetivação, segundo Dahrendorf, do domínio. ${ }^{21}$

Portanto, a continuidade dessa postura quase dogmática conduz à ficção de tentar estabilizar as relações sociais mantendo a ordem estabelecida. Consolida-se a Justiça estática em se fazer compreender como a fonte última dos anseios sociais, razão então para cumprir suas determinações como guardião da promoção da igualdade jurídica entre todos os segmentos sociais sem distinção, não havendo a necessidade de considerar qualquer ator social, econômico etc. O objetivo tradicional é manter a ordem vigente segundo a própria vontade dos seus membros.

Acrescenta-se, como gravame, a elasticidade que se dá ao alcance do significado da cidadania para manutenção do status quo: o teor do contrato social, isto é, o liberalismo, difunde a concepção contratualista para justificar o Estado como um contrato que pressupõe partes e essas partes são os cidadãos. Uma relação que envolva interesses conflitantes entre o Estado e os governados (fundamentados na cidadania) pode ser resolvida a favor daquele, como entidade formada pela própria sociedade - que é a expressão da cidadania. Logo, havendo confusão entre as partes, a vontade do Estado é soberanamente mais significativa.

Com efeito, sob o prisma da classe dominante, nada poderia ser mais legítimo como a afirmativa segundo a qual a cidadania é também exercida no e pelo Estado e, por isso, deve ceder a pressões de um interesse maior que é a própria cidadania contida no Estado, que através de seus órgãos, utiliza um sistema de idéias, símbolos e argumentos para enfraquecer a criticidade da ordem social estabelecida. O impedimento da propagação de novos valores, de nova consciência do exercício da cidadania, é fundamental para ocultar os desequilíbrios sociais. ${ }^{22}$

21 “1. O domínio designa uma relação supra de subordinação entre dois indivíduos ou grupos; 2. Espera-se da parte supra-ordinada (indivíduo ou grupo) que controle a conduta da parte subordinada por meio de ordens, indicações, advertências ou proibições; 3. Esta expectativa está unida a uma posição social que, teoricamente, é independente do caráter peculiar da pessoa que a detém [...] Sanciona-se a desobediência por certas prescrições em razão do domínio; um sistema de Direito (ou melhor, um sistema de normas quase jurídicas) vigia a efetividade do domínio". DAHRENDORF, Ralf. Op. cit., p. 144.

22 "O maior de todos os perigos para o sistema capitalista consiste em que mais e mais pessoas, principalmente das classes subordinadas, cheguem a considerar não só como desejável mas também como possível uma ordem social totalmente diferente, baseada na propriedade social de pelo menos uma parte predominante dos meios de atividade econômica e dedicada à eliminação do privilégio e do poder desigual. E, ainda, de que as 'massas' busquem dar expressão a tal crença em termos de ação política". MILIBAND, Ralf. O estado na sociedade capitalista. Rio de Janeiro: Zahar, 1972, p. 316. 
Ademais, até a tradicional forma de investidura dos membros das Cortes Superiores do Brasil evidencia o nível de dependência aos outros Poderes, passando por uma triagem do Legislativo ao Executivo até a escolha daquele que preencha os requisitos constitucionais. Não se tem notícia sequer de discussão séria no Congresso Nacional de alteração dessa forma de vinculação. Enquanto os parlamentares, o presidente da República e governadores dos Estados submetem-se à vontade do voto popular, pelo menos poder-se-ia pensar, não no voto direto, porém ao menos se submetendo diretamente à votação dos seus pares, sem qualquer interferência posterior dos outros Poderes. Até a vitaliciedade é anúncio da manifestação conservadora à manutenção do status quo.

A dormência da legitimação da dominação através do tradicionalismo parte do pressuposto de que a realização da justiça formal na sua atuação realizará a vontade do direito entre particulares. O Estado, quando demandado, responde pelos atos praticados contra o indivíduo-cidadão, não o próprio exercício da cidadania numa esfera socialmente mais abrangente. Conflitos dessa magnitude são resolvidos considerando qual a malefícia repercussão ao Estado e a sua própria estrutura. Quando os direitos dos indivíduos não dão azo às responsabilidades maiores do Estado perante a sociedade, a aplicação deles é feita de forma estabelecida mediante a articulação dos processos de conhecimento pleno, sem amarras psicológicas. No outro sentido, o peso da "responsabilidade" é mensurado pelo viés político-ideológico.

Sobre essa invocação da significância da difusão das decisões do Judiciário, justifica Perelman:

Um dos principais atributos dos poderes Legislativo e Executivo será seu poder de apreciação em matéria de interesse geral, exercendo o Poder Judiciário, nessa área, quando muito um controle marginal, a fim de prevenir abusos manifestos [...]. A existência de um Poder Judiciário independente, capaz de restringir a arbitrariedade dos outros poderes e de assegurar o respeito ao direito, em especial ao princípio de igualdade perante a lei, fornece entre garantia contra o tratamento desigual daqueles que se encontram na mesma situação jurídica. Mas, quando as situações são diferentes, competirá aos Poderes Legislativo e Executivo decidir, em nome do interesse geral, se as diferenças devem ou não ser levadas em consideração. ${ }^{23}$

Portanto, o exercício da função do Poder Judiciário está vinculado à intensidade do discurso ideológico do aparelho estatal a que pertence. Novas categorias de aplicação da justiça formal como fonte de concretização de um dos pilares da democracia brasileira (cidadania) dependem do nível de valorização que se atribua

${ }^{23}$ PERELMAN, Chaïm. Ética e direito. São Paulo: Martins Fontes, 1999, p. 235. 
ao Poder Judiciário como confirmação da autonomia da sociedade participativa e solidária. ${ }^{24}$

Seguindo a esteira do pensamento de Weber quanto à legitimidade de uma ordem, a judicialização pode ser realizada através da convicção da validade absoluta dos postulados constitucionais à plena eficácia da democracia representativa, tanto de expressão maior da edificação de uma sociedade menos desigual, mais equilibrada, mesmo porque a fonte da autoridade do Estado é a soberania popular. Assim, ao juiz compete, no primeiro plano, identificar-se enquanto cidadão dotado de valores e compromissos históricos para, em seguida, justificar-se enquanto ser em movimento. Através de sua sentença afirmará ou não a cidadania como forma principiológica do Estado Democrático de Direito. ${ }^{25}$

A implantação da judicialização da política deve partir do reconhecimento de sua cumplicidade pela manutenção do risco que o imobilismo político causará à efetivação das conquistas sociais de uma nação. Mantê-la resignada, submissa, atenta contra a vontade participativa incrustada na consciência-cidadã. Negar o exercício da cidadania é negar a própria existência da federação. ${ }^{26}$

A implementação do exercício da cidadania pressupõe promover a dignidade humana na exata condição de sujeito moral e político. Entretanto, depende do Judiciário o exercício dos direitos inerentes a esta condição histórica. A cidadania amorfa, inconseqüente, não corresponde ao grau de sociabilidade que a coletividade procura alcançar.

A solidez da organização social deriva de sua consciência reflexa como mentora do próprio desenvolvimento sem os dogmas ou axiomas elaborados para negar a condição de autonomia de sua participação nos planejamentos das políticas públicas. Negar o movimento dialético das relações sociais é manter ou tentar manter a alienação através da sutileza de argumentos falsos ou falhos da montagem ideológi-

\footnotetext{
24 “Os juizes, podia ser e era afirmado (e, de fato, ainda é), não estão preocupados com o que a lei deveria ser, mas apenas com o que ela realmente é [...]. Soma-se a isso o fato de ser tão importante para o Judiciário evitar envolver-se em decisões políticas que em casos de incerteza, quando opções tinham de ser inevitavelmente feitas, estas deviam sê-lo mais na base de coerência lógica do que em alguma base manifestamente 'extralegal', como o propósito social, a moralidade, a justiça ou a conveniência". LLOYD, Dennis. A idéia de lei. São Paulo: Martins Fontes. 1998, p. 331.

${ }^{25}$ HESSEN, Johannes. Filosofia dos valores. Coimbra: Armênio Amado. 1980, p. 25.

26 "Manifestando-se ou não essas tendências anticonstitucionais, o constante recurso da minoria ao Tribunal Constitucional, como forma de solução de seus conflitos com a maioria, nos leva ao tema da 'judicialização da política', isto é, ao crescente controle efetuado por órgãos judiciários sobre as decisões políticas". MAUÉS, Antonio Gomes Moreira; LEITÃO, Anelice F. Belém. Dimensões da judicialização da política no Brasil - As ADIN's dos partidos políticos. In: SCAFF, Fernando Facury. Constitucionalizando direitos - 15 anos da Constituição Brasileira de 1988. Rio de Janeiro: Renovar, 2003, p. 7.
} 
ca alienante do "interesse público" ou "interesse da nação". Segundo o pensamento de Marcos Bach:

O objetivo imediato da atividade de um magistrado (seja ele religioso ou civil) é a promoção moral da comunidade humana a que serve. Esta, por sua vez, não é idêntica à ordem. A qual, portanto, não pode ser identificada com as necessidades e exigências de um sistema. O conflito entre autoridade e liberdade de consciência ocorre as mais das vezes em virtude de uma formação errônea do conceito de autoridade e ordem e sua relação com o desenvolvimento moral de uma comunidade. Tratar os seus membros como 'menores' do que são na verdade, não é o modo mais inteligente de conduzi-los à maioridade ética e social. A autonomia moral não constitui nenhuma ameaça séria ao exercício legítimo da autoridade. Somente não se dá com o arbítrio, o autoritarismo, o absolutismo. ${ }^{27}$

\section{Conclusão}

A atividade do exercício da cidadania envolve conflitos, sentimentos multiformes das classes sociais que expõem a concorrência entre seus atores. Por outro lado, a existência desses conflitos é o cenário necessário para a participação judicial na determinação do consenso que se pretende. A concretização do status de cidadania representa os interesses coletivos em suas adversidades inerentes, mas que se supera na representação da unidade, desde que realmente haja liberdade para o cumprimento dos desígnios constitucionais de representação plúrima. Portanto, desses interesses fracionados e legítimos ao consenso com as garantias da maturidade do discernimento.

Os ditames constitucionais não podem ser obstados pela coerção originária do Judiciário. O Estado não pode fazer que a cidadania se abstenha de praticar suas ações de realização da participação cooperadora da gestão pública para a satisfação de suas necessidades enquanto ser humano, social e partícipe do seu próprio desenvolvimento. A cidadania é a explicitação da liberdade política, e ao Estado (Judiciário) cabe proporcionar as condições extrínsecas desse valor, mesmo porque o Estado é a expressão do instrumento da unidade a partir da adversidade, do dissenso.

A essência do conservadorismo não é apenas o descaso quanto ao destino do homem, porém é o controle sobre esse destino sem a utilização dos postulados racionais, mantendo-o num determinado patamar social sem a oportunização de galgar novos espaços. Forma-se, pois, uma sociedade legitimada pelo tradicionalismo de uma autoridade (Estado), cujo padrão de conduta central envolve-se em postula-

${ }^{27}$ BACH, J. Marcos. Consciência e identidade moral. Petrópolis: Vozes, 1985, p. 195. 
dos dogmatizados, ao mesmo tempo em que difunde a negação da oportunidade, da habilidade e das manifestações socialmente eficientes.

A sociedade não é estática. Seu movimento, principalmente em razão do acúmulo de informações produzidas pela globalização e informática, direciona-se no sentido de melhores conquistas sociais e pelas oportunidades de se integrar no contexto histórico-social em que vive.

Evidenciada a crítica do alcance do conservadorismo da dominação à alienação não mais aceito pela sociedade. Abalado em suas estruturas não-democráticas, o Judiciário ainda concebe o direito como o conjunto de normas dispostas a delimitar a liberdade dos cidadãos, se necessário com coerção. A crise por que passa é resultado do envelhecimento na estratégia opressora da ordem do direito e do Estado. Parece que para o Judiciário a cidadania representa o problema da isenção intelectual, política e social que moldura o homem-juiz. Não é isso que a cidadania almeja, isto é, tornar a justiça parcial. Seu objeto é apenas ter reconhecido seu status de ator político para exercer os postulados de uma sociedade moderna e em constante movimento. A garantia de exercer suas atribuições é o que se prioriza e não transformar o Judiciário em outro papel que compete ao Legislativo.

A sociedade moderna caminha não mais para aceitar a dominação sob coerção, partindo de pressupostos absolutos e irracionais em favor do Estado. A crítica e o atual inconformismo social não estão mais em acatar como "justa" a dominação imposta pelas convenções tradicionalistas do Estado, mas a liberdade de legitimação em que é vedado a qualquer ente público o emprego de meios de opressão e exploração.

O que a cidadania busca é o liame, é o vínculo concreto com as esferas dos órgãos do Estado como fonte de seus direitos, num âmbito de flexibilidade e estabilidade não apenas formais, porém pela reciprocidade na construção de um ordenamento de respeito às tarefas públicas. A sociedade não é mais alienada, ao invés ela é fonte de legitimação das relações desenvolvidas pelas políticas públicas não mais dentro de uma verticalidade, porém na horizontalidade das práticas democráticas.

A erosão do Judiciário ocorre em razão de dissocialização de seu papel voltado ao conservadorismo e de um órgão amarrado no discurso de promotor último do "equilíbrio do Estado e a harmonia social". Contemporaneamente poucos são os membros do Judiciário que percebem que a sociedade questiona o conceito de cada expressão: "equilíbrio do Estado" e "harmonia social", pilares do tradicionalismo e pilares também da democracia participativa. 


\section{Referências}

ADEODATO, João Maurício. Ética e retórica. São Paulo: Saraiva, 2002.

ALBUQUERQUE, Newton de Menezes. Teoria política da soberania. Belo Horizonte: Mandamentos, 2001.

BACH, J. Marcos. Consciência e identidade moral. Petrópolis: Vozes, 1985. BOBBIO, Norberto. O futuro da democracia. São Paulo: Paz e terra, 1987. BONAVIDES, Paulo. Curso de direito constitucional. São Paulo: Malheiros, 1993.

CALAMANDREI, Piero. Eles, os juízes. São Paulo: Martins Fontes, 1995. DAHRENDORF, Ralf. Sociedade e liberdade. Brasília: UNB, 1981. GARAPON, Antoine. O juiz e a democracia. Rio de Janeiro: Revan, 2001. HESSEN, Johannes. Filosofia dos valores. Coimbra: Armênio Amado. 1980. KELSEN, Hans. Teoria geral do direito e do estado. São Paulo: Martins Fontes, 1995.

KÜSTER, Ângela. Democracia e sustentabilidade, experiências no Ceará, Nordeste do Brasil. Fortaleza: Konrad Adenauer, 2003.

LIMA, Martônio Mont'Alverne Barreto. Judicialização da política e comissões parlamentares de inquérito: um problema da teoria constitucional da democracia. In: SCAFF, Fernando Facury. Constitucionalizando direitos - 15 anos da Constituição Brasileira de 1988. Rio de Janeiro: Renovar, 2003.

LLOYD, Dennis. A idéia de lei. São Paulo: Martins Fontes. 1998.

LUCAS, John Randolph. Democracia e participação. Brasília: UNB, 1975.

MABBOTT, J. D. O Estado e o cidadão. Rio de Janeiro: Zahar, 1968.

MACINTYRE, Alasdair. Justiça de quem? Qual racionalidade? São Paulo: Loyola, 1991.

MAUÉS, Antonio Gomes Moreira; LEITÃO, Anelice F. Belém. Dimensões da judicialização da política no Brasil - As ADIN's dos partidos políticos. In: SCAFF, Fernando Facury. Constitucionalizando direitos - 15 anos da Constituição Brasileira de 1988. Rio de Janeiro: Renovar, 2003.

MILIBAND, Ralf. O estado na sociedade capitalista. Rio de Janeiro: Zahar, 1972.

PERELMAN, Chaïm. Ética e direito. São Paulo: Martins Fontes, 1999. 
ROCHA, José de Albuquerque. Estados sobre o Poder Judiciário. São Paulo: Malheiros, 1995.

RUBY, Christian. Introdução à filosofia política. São Paulo: UNESP, 1997. SARTORI, Giovanni. Engenharia constitucional. Brasília: UNB, 1996. 